\title{
41919
}

\section{For Whom the Bell Tolls: \\ Memeing French Landscape on Instagram}

Meredith L. Pruden

\section{Resumo:}

Na noite de 15 de abril de 2019, várias nuvens de fumo irromperam da Catedral de Notre-Dame e atravessaram os telhados da lle de la Cité em Paris, França. Os líderes mundiais expressaram as suas condolências pela perda e muitos especialistas alertaram publicamente que, embora possa ser reconstruído, o monumento ao catolicismo do século XII nunca "será o mesmo". No final do dia seguinte, os sinos da catedral dobraram ecoando nos céus da cidade em homenagem ao devastador incêndio e centenas de milhões de euros já haviam sido prometidos, com os super-ricos a liderar o caminho. Nos dias que se seguiram, os esforços com o incêndio e a angariação de fundos atraíram uma verdadeira tempestade mediática e provocaram um enorme fervor nas redes sociais. A hashtag \#NotreDameFire liderou no Twitter, tornou-se viral no Facebook e, até ao momento, conquistou quase 22.000 posts no Instagram. Grande parte deste discurso popular on-line não tem sido amistoso e pode ser lido como uma forma de luta política em torno do significado e da identidade de Notre-Dame travada no arquivo digital do Instagram. Este artigo examina a hashtag \#NotreDameFire no Instagram, interpretando os elementos visuais aí publicados através dos conceitos propostos por Cara A. Finnegan em Making Photography Matter: A Viewer's History from the Civil War to the Great Depression. Considera os conceitos de Finnegan de presença, caráter, apropriação e magnitude no contexto do Instagram entendido como um arquivo que funciona, neste caso, simultaneamente, como lugar e visão de uma paisagem imperial a Catedral de Notre-Dame.

Palavras-chave: mídias sociais; teoria descolonial; cultura visual; Catedral de Notre-Dame. 


\begin{abstract}
:
On the evening of April 15, 2019, hoary plumes of smoke erupted from Notre-Dame Cathedral and rolled across the rooftops of the lle de la Cité in Paris, France. World leaders expressed their condolences over the loss, and many experts publicly warned that, though it can be rebuilt, the 12th-century monument to Catholicism will never "be the same". By the end of the next day, cathedral bells tolled across the city in honor of the devastating fire and hundreds of millions in euros already had been pledged, with the uber-wealthy leading the way. In the days that followed the fire, the fire and fundraising efforts garnered a veritable tempest of media coverage and ignited a social media fervor. The hashtag \#NotreDameFire trended on Twitter, spread virally across Facebook and, to date, has garnered almost 22,000 posts on Instagram. Much of this online popular discourse has not been as kind and can be read as a form of political struggle around the meaning and identity of Notre-Dame waged on the digital archive of Instagram. This article examines the \#NotreDameFire hashtag on Instagram, reading the associated visuals through the framework set out by Cara A. Finnegan in Making Photography Matter: A Viewer's History from the Civil War to the Great Depression. It considers Finnegan's presence, character, appropriation and magnitude in the context of Instagram as an archive of, in this case, both site and sight of one imperial landscape - Notre-Dame Cathedral.
\end{abstract}

Keywords: social media; decolonial theory; visual culture; Notre-Dame Cathedral.

\title{
Introduction
}

On the evening of April 15, 2019, hoary plumes of smoke erupted from Notre-Dame Cathedral and rolled across the rooftops of the lle de la Cité in Paris, France like fog languishes across a riverbed on a warm Southern morning. Paris firefighters battled the blaze, which prompted the evacuation of the renowned French Gothic church during evening mass, throughout the night, as flames licked the night sky and Parisians and tourists alike looked on in bewilderment. The rest of the world, too, feared the worst, watching the shadowy orange glow pulse in strange rhythms out from behind the rose windows and across the screens of their televisions, tablets and smart phones. By morning, the catastrophic blaze had toppled the historic building's iconic 295-foot central spire and overtaken its northern transept and wooden roof, which is affectionately known as the "forest" because more than 13,000 oak trees were felled to construct it (Prior, 2019, para. 5). Amazingly, no one was killed, and there was only one reported injury. Moreover, the twin bell towers, the stained glass rose windows, the flying buttresses and much of the priceless art held inside survived the inferno. Even the 16 statues surrounding the church's destroyed spire were spared, having been removed only days 
prior due to ongoing renovations. Nevertheless, many experts publicly warned that, though it can be rebuilt, the 12th-century monument to Catholicism will never be the same (Eustachewich \& Perez, 2019).

Rebuilding is exactly what French president Emmanuel Macron plans to do, according to reports from The Guardian, BBC, Reuters and other news sources. Even as world leaders (including Barack and Michelle Obama, Hillary Clinton, Mike Pence, Theresa May, Queen Elizabeth, Pope Francis, and other political and religious heavyweights from Greece, Italy, Australia, Japan, Egypt and many others) expressed their condolences over the loss (and as Donald Trump now infamously suggested using "flying water tankers" to quell the fire (Trump, 2019, April 15)— much to the apparent chagrin of the Paris Fire Department), Macron announced via Tweet that an international fundraising campaign would be launched on April 16 to rebuild Notre-Dame (Macron, 2019, April 15). By the end of the day on April 16, cathedral bells tolled across the city in honor of the devastating fire and hundreds of millions in euros already had been pledged, with the uber-wealthy leading the way. According to an NPR (2019) report by Gonzalez \& Horsley, a small set of international elites and major companies, including François-Henri Pinault (Kering; married to Salma Hayek), Bernald Arnault (LVMH), the Bettencourt Meyers family (L'Oreal), Henry and Marie-Josée Kravis (private equity), Apple and Total had pledged upward of 600 million euros to the cause. By the next day, April 17, that number had soared to at least 845 million euros or the equivalent of $\$ 950$ million USD, as Disney, the University of Notre Dame and Assassin's Creed creator Ubisoft each pledged funds toward the reconstruction (Breeden, 2019, para. 5).

Macron also announced plans to rebuild Notre-Dame within five years in time for the Paris 2024 Olympics, noting the difficulties this timeline may pose even as the French government began circulating rumors of a contest to redesign the cathedral's lost spire. French Prime Minister Edouard Philippe said the competition would "allow us to ask the question of whether we should even recreate the spire as it was conceived by Viollet-deLuc... or if, as is often the case in the evolution of heritage, we should endow NotreDame with a new spire" (Lough \& Pailliez, 2019, para. 5). Adding to the architectural masterpiece has a long history dating back through the centuries, Philippe is referencing Notre-Dame's many previous renovations and additions. To be sure, the behemoth building has evolved over time, but the spire dates back only to the early half of the 19th century when architect Eugene Viollet-le-Duc designed and oversaw its construction. At the time, it was, apparently, considered quite gauche but since has become arguably the most recognizable symbol of the cathedral. Though the official contest has not yet been launched at the time of this writing, redesign concepts (of varying quality) already are somewhat prolific online. 
Re-imaginings of the beloved spire are not the only abundant Notre-Dame fire-related hits that turn up online. A Google search of "notre dame fire" at the time of this writing results in more than 4.7 million hits. Furthermore, in the days that followed the fire, the event garnered a veritable tempest of media coverage, with a ProQuest search for "notre dame" and "fire" between the dates of April 15 and April 30, 2019 turning up more than 6,000 results in five languages (French, English, Spanish, Russian and Urdu) across global newspapers, wire services, blogs, podcasts, websites, trade publications, magazines and audio/visual segments. The most recent coverage outlines Paris investigator's theories about possible causes, including worker negligence with smoldering cigarette butts and a short-circuit in the spire's electric bells. It seems, from a cursory overview of these ProQuest hits, that much of the coverage (particularly in mainstream and legacy media news stories) is straight reporting about the fire as events unfold with relatively little pushback or critique. Unsurprisingly, however, all of the money raised by high profile donors, attention from world leaders, competing design contests and widespread media coverage also ignited something of a social media fervor surrounding the Notre-Dame fire. The hashtag \#NotreDameFire trended on Twitter, spread virally across Facebook and, to date, has garnered almost 22,000 posts on Instagram with another 1,400 posts nested under similar but less popular hashtags. Much of this online popular discourse has not been as kind and can be read as a form of political struggle around the meaning and identity of Notre-Dame waged on the digital archive of Instagram.

This paper examines the \#NotreDameFire hashtag on Instagram, reading the associated visuals through the framework set out by Cara A. Finnegan in Making Photography Matter: A Viewer's History from the Civil War to the Great Depression. This paper does not employ a content analysis method or select images from the curated hashtag because of frequency of appearance. Instead, all images in the population were viewed and a set of images was selected that seem to be representative of the different visual rhetorics contained in the hashtag. It considers Finnegan's presence, character, appropriation and magnitude in the context of Instagram as an archive of, in this case, both site and sight of one imperial landscape - Notre-Dame Cathedral. Although it is not a landscape in the traditional sense ("a natural scene mediated by culture"), NotreDame as a medieval manmade structure has become a naturalized representation of the Parisian landscape (Mitchell, 1994: 7). Indeed, the world famous cathedral may be one of the most recognizable sites and sights in all of Europe. But, it does not only appear as a prolific 'must-see' in the travel and tourism magazines, it also houses countless treasures looted from former French colonies and remains a symbol of French imperial history. This is, to quote W.J.T. Mitchell, a "hard fact' embedded in idealized settings" 
helping us to consider how landscape is bound up in politics, ideology and imperialism (Mitchell, 1994: 7; 9).

\section{Making Photography Matter}

In Making Photography Matter, Finnegan applies her background as a rhetorician to study viewer responses to historic photographs. She does this by identifying discursive evidence of these responses left in other related historical artifacts, such as newspapers, comment cards, speeches, trial testimony transcripts and many more. Although Finnegan lays out a framework specifically for studying the textual discursive traces of photography's first one hundred years as evidence of a developing "rhetorical consciousness" that can be attributed to photography, my aim here is to extend her work to the discursivity of the image itself - this, of course, entails thinking of images beyond photography (Finnegan, 2015: 2). This objective is especially relevant within digital spaces, specifically social media, where image often seamlessly blends with text, where the speed of dissemination often lends itself to real-time conversation and where current events often spread virally around the globe in hours or even minutes. As Finnegan suggests, this is of particular importance when one considers that "photography may be understood as an art of the contingent, a visual habit of picturing social, political, and cultural life" (Finnegan, 2015: 5). Perhaps, for our purposes here, photography and other art also can picture imperial sites and sights on the Internet.

Broadly, Finnegan's framework acknowledges that photography (or, for our purposes here, images) have four capacities. The first capacity is to "produce presence in the face of profound, and often permanent, absence" (Finnegan, 2015: 2; emphasis in original). According to Finnegan (2015: 48), presence is more than visual - it is affective, sensual and collapses time and space in a way that "open[s] a place for viewers to remake what they see". In this way, it matters far less whether an image represents the 'objective truth' of a person, place or event and much more how an image elicits agency within the viewer that enables them to "engage in complex meaning-making practices" (Finnegan, 2015: 49). The second capacity is to communicate character (or ethos), which Finnegan (2015: 54 ) argues is not only a foundational principle of rhetoric but also not only about the speaker. Instead, ethos also is about the audience as a community and its ability to tap into social knowledge and shared cultural narratives attached to collective heritage and identity (Finnegan, 2015: 61). Using an early and previously unknown photograph of Abraham Lincoln published in McClure's magazine, Finnegan (2015: 78) illustrates how viewer responses to this image relied on the frontier myth to shore up the notion of American exceptionalism by appealing to Lincoln's perceived character traits "as a synecdoche for the nation's character". 
The third capacity is that of appropriation, which works to reposition the subject of the image by commandeering the structure, style and strategies of other popular communication (e.g. media narratives). Drawing on several other scholars, Finnegan (2015: 88) outlines these three levels of appropriation thusly: "where structural appropriation happens at the level of conventions and social norms, and stylistic appropriation works in the middle space of the formal or aesthetic, strategic appropriation operates in a more situated and instrumental sense... used to further one's immediate persuasive goals". Importantly, much like social media, Finnegan's (2015: 91) case study here draws on a book that combines "vivid textual description with the presentation of visual images". She traces this back to the muckraking tradition, which included not only vivid description and heavy use of imagery but also direct address to the intended viewer and "rhetoric designed to shame" (Finnegan, 2015: 95). Moreover, in this chapter, Finnegan (2015: 96) explicitly addresses other visual modalities than photography, including illustrations, which are common throughout the \#NotreDameFire hashtag. In the context of this hashtag, which uses Notre-Dame as landscape, this type of visual appropriation also functions as a "medium of exchange... for the formation of identity" for Instagram users (Mitchell, 1994: 2).

Finally, the fourth capacity is to mobilize magnitude, which Finnegan (2015) defines by drawing on the work of Thomas Farrell as possessing gravity, enormity, weightiness and significance. She argues that documentary photos in particular "constitute a visual medium par excellence for enacting magnitude: Look at this. This is important" (Finnegan, 2015: 130; emphasis in original). That said, according to Finnegan (2015), humans need to be able to manage magnitude lest it become overwhelming. In the case of the Farm Security Administration's (FSA) exhibition at the 1938 First International Photographic Exposition in New York City, Finnegan (2015: 131) argues viewers managed magnitude in four distinct ways: "by identifying with the photographs as 'real,' educational documents of social fact; by using a popular language... grounded in disassociation, irony, and shame; by demanding public policy action; and by advocating for greater publicity and circulation of the photographs". As we will see later in this essay, \#NotreDameFire images circulating on Instagram not only mobilize and manage magnitude but also produce presence and appropriate popular narratives in similar ways to the cases in Finnegan's work.

Taken together, the four capacities of presence, character, appropriation and magnitude in the context of \#NotreDameFire as digital archive on Instagram represent not only "imperial views" but also resistance to this framework. In both cases, on each side of the struggle, the site and sight of Notre-Dame Cathedral functions as landscape (Mitchell, 1994). 


\section{Visual Culture in the Digital Space}

In the age of digital culture, conceptualizing image reproductions as decontextualized and operating outside time and space, as did Walter Benjamin (2010: 13), seems a fool's errand. In fact, far from losing authenticity (or aura) in both the original and the reproduction and, subsequently, the ability to act as historical testimony with any authority (or meet the viewer halfway), images circulating on social media often gain cultural power not only through circulation but also through vanity metrics such as shares, likes, re-grams and the like. To be sure, images circulating on social media platforms such as Instagram are based on exhibition value rather than cult value, as Benjamin suggested. Moreover, their 'truth value' increasingly is called into question in the era of 'fake news' and increased technological ability for image manipulation (McIntyre, 2018; Pickard, 2016). However, social media amplifies "the cult of remembrance" in ways Benjamin, writing in 1936, never could have imagined (2010: 21). That said, Benjamin (2010: 43) did inadvertently hint at the rise of social media with his comments about the masses as a "matrix from which all traditional behavior toward works of art issues today in a new form". This becomes particularly salient for our purposes here around \#NotreDameFire when considering Benjamin's (2010: 43-43) views on architecture as a "living force" consumed by a collective group of people in a state of distraction. According to Benjamin (2010: 44):

Architecture has never been idle. Its history is more ancient than that of any other art, and its claim to being a living force has significance in every attempt to comprehend the relationship of the masses to art. Buildings are appropriated in a twofold manner: by use and by perception - or rather, by touch and sight. Such appropriation cannot be understood in terms of the attentive concentration of a tourist before a famous building. On the tactile side there is no counterpart to contemplation on the optical side. Tactile appropriation is accomplished not so much by attention as by habit.

Benjamin (2010: 44) saw appropriation (theoretically distinct from Finnegan's appropriation) as the way in which architecture acquired "canonical value" because perception is gained or changed by tactile habits and not by contemplation alone. In short, he believed that even distracted people can form habits and master them. This clearly is true in the case of social media, where tactility (the swiping of the phone screen, the clicky tapping of the computer keys, the mashing of the home or volume button) connects the distracted matrix of the masses not only to content but also to each other through a modern structure of networked communication - if only for a fleeting moment at a time. Would Benjamin see \#NotreDameFire images on Instagram as somehow more 
alive than Notre-Dame Cathedral itself locked in the gaze of one of the astonished witnesses to the event that fateful evening? Perhaps. What is more clear, as Panofsky (1955) points out, is that all art includes its material form (in this case digital as embodied through a technological device), the idea or subject matter (in this case the Notre-Dame Cathedral fire as landscape) and the content (which varies according to the image). Additionally, "there is no such thing as an entirely 'naive' beholder" (Panofsky, 1955: 16). Instead of a 'naive beholder', in Panofsky's (1955) work we see a person who "not only enjoys but also, unconsciously, appraises and interprets the work of art" and in which "no one can blame him if he does this without caring whether his appraisal and interpretation are right or wrong, and without realizing that his own cultural equipment, such as it is, actually contributes to the object of his experience" (Panofsky, 1955: 17). This is exactly the agency that Finnegan suggests allows viewers to make meaning from images and also points to the landscape as a tool of cultural and social identity as Mitchell argues. Although Notre-Dame Cathedral itself is a symbol of the French colonial legacy, it becomes a site/sight of contestation using the \#NotreDameFire hashtag on Instagram. Moreover, as Finnegan \& Kang (2004: 395) argue, drawing on the work of Warner, Latour and others, a key component of agency is the act of recognizing the mediation or circulation of an image. This recognition of the image as a mediated and re-circulated entity produced and shared by human beings in a continuous feedback loop not only removes the very human tendency to judge an image as inherently "true" or "false" but also to recognize the decontextualized, hidden (and sometimes consciously erased) history of the images that help construct our worldview (Finnegan \& Yang, 2004: 395). For this process to work, a viewer must be granted agency. One way this type of agential contestation can occur, according to Dahlgren (2009: 34), is through media alterations that circulate within the public sphere. This is particularly true in the contemporary context, in which proliferation, concentration, deregulation, globalization and digitization have become the new norm and in which traditional journalism has come under steady fire from both market pressures and changing audiences (Dahglren, 2009: 35-40). Moreover, political communication is in flux due to pluralization and shifting power dynamics, according to Dahlgren (2009: 54), which has resulted in what he terms a media matrix that includes the digital space.

In the case of images disseminated across social media platforms such as Instagram, specifically \#NotreDameFire, we see not only a colonial legacy or agential viewers but also participatory cultures. As defined by Jenkins, Ito \& boyd (2016: 4),

A participatory culture is a culture with relatively low barriers to artistic expression and civic engagement, strong support for creating and sharing 
one's creations, and some type of informal mentorship whereby what is known by the most experienced is passed along to novices. A participatory culture is also one in which members believe their contributions matter, and feel some degree of social connection with one another (at the least they care what other people think about what they have created.

This is not to say that participatory cultures exist only online (they do not); however, it is clear that social media platforms fit the bill - they carry low barriers of entry, include a culture of support for content generation and sharing and often exhibit a deeply felt sense of social connection. Although informal mentorship is somewhat more difficult to ascertain in these spaces, the sharing of advice and how-tos online does indicate (at least anecdotally) a loose network of available guidance for members. Importantly, participatory culture does not preclude hierarchical power relations within the group and is not mutually exclusive with colonial legacies. As these authors point out, "even with very open, participatory cultures with low barriers to entry, people find ways of maintaining status and distinction" (Jenkins, Ito \& boyd, 2016: 20). This is, of course, a remnant of a colonial mindset or what Stoler calls "colonial presence" - a recursive colonial history that frames contemporary meaning-making and identity through an imperial lens (Stoler, 2016: 123). Even a participatory culture can engender and disseminate colonial ideas while at the same time and, perhaps paradoxically, defying them. As Stoler (2016: 122-123) asserts specifically related to French colonial history ( $p$. 122-23):

Colonial histories possess unruly qualities... Not least, they raise unsettling questions about what it means to know and not know something simultaneously, about what is implicit because it goes without saying, or because it cannot be thought, or because it can be thought and is known but cannot be said... My interest is in the peculiar conditions that have rendered France's colonial history alternately irretrievable and accessible, at once selectively available and out of reach.

The \#NotreDameFire hashtag is an apt illustration of this paradox. Nevertheless, participatory cultures that grow up around social media platforms do provide members social capital, as well as help to shape cultural norms and tastes. In the case of hashtags like \#NotreDameFire and others, a certain sense of kinship is constructed around common causes, concerns and life events. In this case, a kinship group has coalesced around the hashtag and, at least in part related to the activism-inspired posts, can be read as a pushback against the colonial visualities of those bemoaning the loss of NotreDame as an imperial landscape. Solidarity via hashtag activism has been documented 
by several scholars (Bonilla \& Rosa, 2015, Loza, 2013; Mottahedeh, 2015; Williams, 2015).

It also is not unusual for affinity or kinship groups to develop around civic engagement and activism within participatory cultures that live primarily in the social media space this is especially true for younger generations. Drawing on the work of Cohen \& Kahne, who define "participatory politics as 'interactive, peer-based acts through which individuals and groups seek to exert both voice and influence on issues of public concern' (2012: vi)," Jenkins, Ito \& boyd (2016: 155) see participatory politics as nested within participatory culture. Moreover, they call specific attention to the ways in which "appropriation and remixing of media content has become a tactic widely deployed" amongst young online activists in particular (Jenkins, Ito \& boyd, 2016: 157). Relevant to \#NotreDameFire images, these tactics also can be deployed in the service of civic engagement that does not necessarily rise to the level of activism; however, participatory politics that find ways to challenge the status quo are "enabled by networked collectives and new media" (Jenkins, Ito \& boyd, 2016: 158). In some cases, according to these authors, participatory politics has not only cultivated activists but managed to change public policy surrounding specific causes. In this way, participatory politics also challenges landscape as a colonial system of visuality. In the case of Instagram posts using the \#NotreDameFire hashtag to push back against the loss of Notre-Dame Cathedral as a paramount concern for international society, we see how solidarity and kinship groups can mobilize to call for attention to issues the group of users considers more pressing - such as the burning Amazon rainforest, big game hunting in Africa and starving children around the world.

This form of remixing and appropriation is not unique to the online space. Huhtamo (2011: 28) traces its legacy to "stereotypical formula[s] evoked over and over again in different guises and for varying purposes". Though not without some criticisms for being overly vague and universalizing, the study of these formulas, or topoi, according to Huhtamo (2011: 30) dates back to the 1930s and Ernst R. Curtius. Curtius was influenced by the Grand Tour ideologies prevalent at that time, as well as by Jung's archetypes and Warburg's iconology; however, topoi likely have been in use since the Dark Ages (Huhtamo, 2011: 29-30). That said, topoi are not consistent - a point to which Huhtamo asserts Curtius did not attend. Instead, they rely on socio-historical context and are "symptomatic of the times and places" in which they were evoked (Huhtamo, 2011: 33).

Two scholars have extended this framework into visual rhetoric and political cartoons techniques widely used in the Instagram corpus of the \#NotreDameFire corpus. Morris (1993: 198-9) sees images as inherently topological and follows earlier scholars, 
including Parsons, in suggesting that cartoons are intimately related to one's social position via practical, emotional, intellectual and political knowledge. According to Morris, there are several elements by which cartoonists can invoke or draw upon topological knowledge. These elements include Gombrich's condensation or compressing "complex phenomenon into a single image that is purported to capture its essence" and combination or "the blending of elements and ideas from different domains into a new composite" (Morris, 1993: 200). A third element is Goffman's domestication, which is a process that takes what is novel, abstract, difficult to understand or unfamiliar and translates it into something "close, familiar, and concrete" through patterns and formulas (Morris, 1993: 201). Lastly, Bakhtin's carnivalization and hypercarnivalization affect form by ritualizing the everyday through stylized representation (Morris, 1993: 203).

Conners (2007) uses Medhurst \& DeSousa's four inventional topoi, including (1) political commonplaces, (2) personal character traits, (3) situational themes, and (4) literary/cultural allusions to suggest popular culture and political cartoons are deeply interconnected because these types of cultural allusions offer a visual shorthand that connects with the viewer/reader (Connors, 2007: 261; 264). Importantly, Huhtamo (2011: 36 ; 40) sees the internet as "an enormous topos transmitter (and perhaps a topos generator as well)" in which they have the capacity to go viral thanks to social media.

\section{\#NotreDameFire on Instagram}

As will be illustrated through an analysis of images and image themes collected using the \#NotreDameFire hashtag, there is an amplified cultural power circulating on Instagram that puts the living force of Notre-Dame Cathedral to use as a form of civic engagement for agential viewers and content creators with not only imperial views but also those with decolonial sensibilities. By "decolonial sensibilities," we mean those that question lingering inequities and, specifically, those affective narratives that connect the Notre-Dame fire to "rubrics of 'security', 'terrorism', 'defense of society' or 'race'” (Stoler, 2016: 13). Importantly, the difference between viewers and content creators is a very blurred line these days. In the case of Instagram, users are one and the same. This dual role makes it possible to analyze only the images in this specific case, as these images constitute viewer responses in much the same way as Finnegan's artifacts do (comment cards, trial testimony or newspapers, for example). The image is the response to the event. Though not yet historical and not always photographs, these images still manage to function through Finnegan's framework of presence, character, appropriation and magnitude and provide a route for decolonial scholars to challenge "imperial views" through landscape. This is particularly true in the critical posts within the \#NotreDameFire hashtag. As we will see based on the afore-mentioned method, many of these critical 
posts employ irony, satire and outright cynicism to challenge the notion that the partial loss of Notre-Dame should take media and societal precedence over what these critics perceive to be more pressing issues of the day. These critical posts apply Finnegan's concepts of presence, character, appropriation and magnitude to challenge the imperial view of Notre-Dame as iconic French landscape. As Mitchell argues, landscape may be the spatially and temporally unmoored "'dreamwork' of imperialism where "unresolved ambivalence and unsuppressed resistance" are negotiated (Mitchell, 1994: 10).

\section{Presence}

If images have the capacity to "produce presence in the face of profound, and often permanent, absence," the partial destruction of one of architecture's most iconic monuments (and lingering vestiges of French imperialism) certainly qualifies as one such scenario (Finnegan, 2015: 2; emphasis in original). Indeed, many people clearly felt an acute sense of loss as the fire at Notre-Dame Cathedral burned into the wee hours of the morning. Evidence of this can be found in the gathering crowds of onlookers praying together, resting their faces in their hands with tears streaming down their faces or singing Ave Maria as they huddled together just across the street. On Instagram, the \#NotreDameFire hashtag granted presence to the cathedral not only as it was engulfed in flames but even today and likely for many years to come. In this way, the spatiality and temporality of both the building and the event itself were (and continue to be), in fact, collapsed and a space was created for viewers on Instagram to "remake" the building and event from symbol of colonial heritage/presence to site/sight of contestation. This remaking and contestation occurs as some Instagram users bemoan the devastation of Notre-Dame as iconic landscape while others push back on that heritage to question public commitment to a building over pressing social issues. This "conversation" is present throughout the corpus, which includes the population of \#NotreDameFire images and functions as a conversation of sorts between those who see the Notre-Dame fire as a profound absence and those critics who view the reaction as overblown in lieu of the more pressing issues already outlined above.

Although there are plenty of rather striking and sometimes heart-wrenching images of Notre-Dame on fire nested within this hashtag, these are not the images that produce presence in the context of Finnegan's framework because they evoke a sense of ongoing action rather than ultimate loss after the fact. While these images are most certainly affective, they fail to collapse time and space - though they may one day do so. Instead, presence primarily is produced in one of three ways - through fine art, through architectural photography of the intact structure and through selfies. In the face of the possible complete ruination of one of the world's most iconic pieces of architecture and 
landscapes, many Instagram users turned to art to address a clearly overpowering sense of loss. The sheer variety of styles of art posted under the \#NotreDameFire hashtag is astounding. There are pencil and line drawings, watercolors and oils, etchings and graphic designs, realist and abstract representations and many other styles - some of which evoke a sense of critique via satire. Some feature people and others do not. In some, the cathedral is aflame and in others it is intact. Some are vibrantly colored and evoke an almost whimsical nostalgia for the monument/landscape, while others are somber and reflect a sense of mourning. Through it all, however, these representations function in a two-fold manner - both of which are imbued with affect and sensuality. First, the user acts as a virtual witness to unfolding events, even as they come to terms with and work through them. Second, the user provides a sense of presence for Notre-Dame Cathedral when they post the finished image of their art to Instagram using the \#NotreDameFire hashtag. In both ways, the user is creating an at least semi-permanent record (archive) of the existence of the cathedral and, in the latter case, the user on Instagram is making virtual travel possible for those far removed from Paris (Finnegan, 2015: 34). In many ways, these personal representations of Notre-Dame construct a more meaningful record of its presence than is possible from the countless collected photographs and illustrations of the cathedral through the years before its destruction because they convey a sense of loss not previously possible.

Another way Instagram users produced presence was by posting photographs of the intact Notre-Dame Cathedral prior to the fire. Like the artistic renderings of the cathedral, these photos also represent a wide variety of styles. There are color and black and white images. Photos with tourists milling about in the background and pristine almost Architectural Digest style images that suggest a professional may have taken them. Photos taken by day and at night and in every season judging by the leaves (or lack thereof) on the trees, blooming flowers or tourist outfits. However, unlike the artistic posts, these photographs produce presence in quite a different way. While the tactility of the artistic posts at least implicitly acknowledges a felt sense of loss, these photographs of the intact monument/landscape seem almost in a state of denial as to unfolding events. I use the term "artistic posts" to refer to Instagram users who are uploading their own paintings, illustrations, etc. and "users" to refer to all other posters. This usage is to acknowledge that Instagram users posting their own art are more than just users of a social media platform. They are artists in the traditional sense. This is not to assert all Instagram users are artists. Unlike the artistic posts, however, it is almost as if these photos stand as a virtual witness to Notre-Dame as it was and will never be again. In this case, these photos make imagined virtual travel possible but to a place no one can ever go back to in quite the same way again. This creates a presence in the landscape itself 
as a medium that both legitimizes and commodifies the cathedral as a cultural and social symbol. As Mitchell said, "Landscape is a medium in the fullest sense of the word. It is a material "means" embedded in a tradition of cultural signification and communication, a body of symbolic forms capable of being invoked and reshaped to express meanings and values" (Mitchell, 1994: 14).

Finally, Instagram users produced quite a different type of presence through the posting of selfies taken at Notre-Dame (a topic that already has received quite a lot of attention online). Nicholas Mirzoeff (2016: 63; 66; 69) suggests selfies are "really about social groups and communications (sic) within those groups" and that there are two kinds of selfie - the most common of which is "the selfie as digital conversation" or "digital performance of the self". In these digital conversations, according to Mirzoeff (2016: 69), selfie takers are performing a socially acquired visual vocabulary that has allowed us to move beyond speech and the written word to a form that is not only information rich but also increasingly "fast, intense, and visual". Much like the photographs of Oliver Wendell Holmes Sr. in Finnegan's discussion of the battle of Antietam, the \#NotreDameFire selfies are authorizing their takers' own experience but differ from Holmes in that they are not privileging "the viewers' experience of encountering the images for the first time" (Finnegan, 2015: 35). Instead, they are privileging the takers' experience as a conversation starter that says, in an extension of the Grand Tour topological narrative, "I was present before Notre-Dame was gone." In this way, we become acutely aware of the presence of the selfie-taking Instagram users, who are not those that can be read as having a decolonial sensibility (Mitchell, 1994). Instead, they are the Instagram users who seem to see France's colonial history as irretrievable (Stoler, 2016).

\section{Character}

If Lincoln's perceived character traits were "a synecdoche for the nation's character," the images and illustrations of Notre-Dame Cathedral being engulfed in communicates character in a similar yet slightly different manner that may, in fact, draw on Connors' application of inventional topoi (Finnegan, 2015: 78). French culture is renowned for its cuisine, its fashion, its art and, perhaps most importantly, its architecture - all artifacts/evidence of its imperial history. At the top of a very long list of famous French architecture (including the Louvre, the Eiffel Tower, the Palace of Versailles and the Arc de Triomphe, amongst others) is Notre-Dame Cathedral. Construction began on NotreDame in 1163, making it the oldest building in Paris still standing today, so it is easy to see why the Paris mayor said the cathedral is "part of our common heritage," President Macron professed that the loss of Notre-Dame as "a terrible tragedy" since the place "is the cathedral of all French... the epicenter of our life" and many Parisians call the gothic 
marvel a "symbol" of French culture and heritage. The shared cultural narrative for the French surrounding Notre-Dame is not only that the cathedral stood in the heart of the country's capital city but also that it played host to major national events and houses a collection of beloved national treasures - many of them looted from conquered peoples during the French imperial reign. For the French people, images of this burning icon no doubt stand in as a synecdoche via condensation and combination for a country in turmoil (Yellow Vest protests $^{1}$, rising gas prices, anti-semitism, a controversial immigration bill) whose national identity (read, white identity) is in peril.

For Catholics across the world, Notre-Dame is second only to Vatican City's St. Peter's Basilica in terms of iconicity. Often a site for pilgrimage and prayer, Notre-Dame still held evening mass each day and was home to many religious relics, including the tunic of Saint Louis, a stone from the Church of the Holy Sepulcher, nails from the cross, a piece of the cross and the crown of thorns, amongst others (the nails, cross and crown of thorns are uncertified). Within France, despite being an increasingly secular nation, even 'lapsed Catholics' recognize the significance of the cathedral to the church and its parishioners. Like the French people, many Catholics likely see images of the broken spire alight in the night sky during Holy Week as a symbol of a broken and woefully out of touch church on the brink of disaster from widespread charges of sexual abuse that largely have gone unrecognized and unpunished. In this case, these images are a synecdoche for a religious identity ravaged by an embroiled church. Of course, there are still many defenders of Catholicism who see images of the untouched golden cross that survived fire as "the forest" fell in on it and see God's divine grandeur, defying scientific explanation. Nevertheless, in each of these cases, the images of Notre-Dame sparkling in the fiery glow of smoke and ember most likely do not so much help viewers "as a rhetorical resource for working out the anxieties of their age" as they reflect those anxieties back out off the screen at them (Finnegan, 2015: 55). Of course, it is impossible to ignore religion as colonial power par excellence in and of itself nor the myriad ways in which religion and imperial nation-states mutually construct and empower one another a fact to which W.J.T. Mitchell (1994) alludes throughout his work.

For other users engaged in meaning-making within the Instagram community surrounding \#NotreDameFire, the ethos of these images challenges taken-for-granted imperial narratives by visually admonishing the assertion that Notre-Dame is more

\footnotetext{
1 The Yellow Vest movement took root in France in 2018, and the revolutionary group continues to regularly protest at the time of this writing. There have been several violent confrontations between police and protestors. Named for the reflective jackets road crews and some motorists wear, the Yellow Vest movement began as a response to rising fuel prices but has grown into a grassroots movement focused on broad issues of economic justice.
} 
worthy of raising millions of dollars as people are starving, the environment is being destroyed and violence is erupting in locations across the planet. These users are tapping into a collective hashtag solidarity to question French cultural supremacy and implicitly its imperial legacy exemplified by the Cathedral.

\section{Appropriation}

Mitchell (1994: 2) argues that "landscape circulates as a medium of exchange, a site of visual appropriation, a focus for the formation of identity" (emphasis in original). If we consider Notre-Dame Cathedral as landscape and view appropriation as working to reposition the subject of an image by commandeering the structure, styles and strategies of other popular communication, memes are probably the most obvious example of appropriation on social media - especially in the highly visual realm of Instagram. Moreover, the style of appropriation found here draws on the visual shorthand suggested by Connors (2007), Huhtamo (2011), and Morris (1993). Although Finnegan's examples of appropriation draw on the muckraking tradition and include references to vivid description and direct address, for our purposes here (and in keeping with Mitchell's understanding of landscape as a surface model), this section focuses only on the structure, style and strategies of the memes as standalone and the "rhetoric designed to shame" contained within them (Finnegan, 2015: 95). It does not include an analysis of the accompanying textual description posted alongside the memes or user comments. Additionally, while Finnegan sees the full-page portrait frontispiece of Dawley's book The Child That Toileth Not as a sort of "visual epigraph" that situates "the author within a particular space and time and hinting that he possesses firsthand experience of the conditions he will describe," in the case of Instagram, it is the hashtag that functions as epigraph (Finnegan, 2015: 99). In the case of \#NotreDameFire, however, the epigraph not only does the work of positioning the author, it also works to "invite the viewer" into the open space as a photograph's caption does for Finnegan (2015: 102). But, what are these memes inviting the viewer into?

Although they certainly do not do so exclusively, many of the memes themselves function as visual rebuttals to the colonial master narrative of the Notre-Dame fire as catastrophe (Finnegan, 2015: 108). They do this by shifting the viewer's attention away from the fire and onto other pressing issues of the day through juxtaposition that constructs a "visual discourse of morality" (Finnegan, 2015: 65). Examples of this juxtaposition include: an illustration of a starving child holding a "save Notre Dame" sign; a photo of a group of malnourished and solemn looking children set underneath a photo of the gutted roofline of Notre-Dame with the caption "When a building is more important than human life... the devil is winning"; A blurry snapshot featuring a young boy stretching awkwardly in an 
attempt to reach the fourth stair step labeled "Notre Dame" from the bottom floor where the boy is "millions of donations" and each step he is skipping represents "world hunger", "Puerto Rico relief" and "uncaging migrant children"; Side-by-side photos of the burning cathedral and the burning rainforest; Four photographs of the jungle, the coastline, a coral reef and a beehive all stamped with the words "rebuild this cathedral"; Another stacked group of photos featuring the burning church set atop a man tenderly touching a forlorn-looking rhinoceros. All of these exemplify the use of juxtaposed imagery to draw attention to the hypocrisy of raising hundreds of millions of dollars for a building when there are people starving, the planet is in peril and animals are going extinct every day to no great fanfare (or great donations). This is the visual rhetoric of shame.

Still other memes appropriate popular culture (especially cartoons as discussed earlier in the context of topoi) to alternatively poke fun at those mourning the loss of Notre-Dame or to illustrate their sadness about the event. There are more than a handful of Photoshopped images featuring dragons burning down the cathedral. To further exemplify the Game of Thrones ${ }^{22}$ theme, there also is a fake news article with Cersei Lannister smiling smugly at the photo of Notre-Dame burning positioned to her right. The headline reads, "Cersei Lannister claims responsibility for Notre Dame (sic) fire," as well as a well-illustrated comic of Daenerys Targaryen telling one of her dragons, "I said that dame! I was talking about Cersei!" as the cathedral burns in the background. While the Disney version of the Hunchback of Notre-Dame (along with his gargoyle buddies, OJ Simpson and a bear on a tricycle) also appears in the police lineup of "Notre Dame fire suspects" that pokes fun at the event, far more of the memes featuring the quintessentially Parisian characters mourn the loss of the great cathedral. In fact, many of the cartoon memes that fall into this category are of either the Hunchback hugging Notre-Dame or of the gargoyles crying. Although it is impossible to know for sure, it seems at least anecdotally possible the prevalence of this style of meme may be the reason Disney decided to donate money to reconstruction. In all cases, these memes rely on what Mitchell (1994: 92; 262) has termed the "imaginative appropriation of landscape" and clearly invoke a "considerable power to mobilize political passions".

\section{Magnitude}

If magnitude is about gravity, enormity, weightiness and significance, the Notre-Dame fire exemplifies deep cultural meaning and importance. It also requires, as Finnegan

\footnotetext{
${ }^{2}$ Game of Thrones was an award-winning HBO fantasy drama series that ran from 2011 to 2019. It was based on George R.R. Martin's book series and featured several rival families fighting for the right to sit on the Iron Throne. Cersei Lannister and Daenerys Targaryen were women from two of the families competing for the throne.
} 
proposes, management to become less overwhelming - this especially is true for Parisians and Catholics who may be enmeshed with the status quo of colonialism or entangled in a colonial presence. The images found within the \#NotreDameFire hashtag suggest some Instagram users are attempting to manage the personal and cultural gravity of the situation through visual mediation. At the most basic level, sharing images of Notre-Dame as it was expresses a deep nostalgic drive, while sharing images of Notre-Dame ablaze can be read as an attempt at catharsis in the wake of unimaginable devastation to national and religious identity. Even the sharing of parodic memes may be read as an attempt to mediate sadness or anger through humor. Ultimately, it is impossible to know through the images alone whether these social media users identify with the images as "'real', educational documents of social fact"; however, we do see the use of "popular language... grounded in disassociation, irony, and shame", as well as a demand for public policy action (though not necessarily related to Notre-Dame) and advocacy for wider circulation through the photos, art and memes discussed in the sections above (Finnegan, 2015: 131).

Read through the lens of Mitchell's (1994) perspective on landscape and imperialism as objects of nostalgia, the ways in which \#NotreDameFire meme creators construct its mediated representation in the digital archive of Instagram also illustrates these memes "magnitude of value" (Mitchell, 1994: 335). Their magnitude of value lies not only in Instagram users' attempts at meaning-making, catharsis or even political struggle but also in the labor involved in creating and sharing them. Within participatory cultures and politics, there is an exchange value to appropriating and remixing content that challenges the status quo and, in the case of critical Instagram users, also challenges Notre-Dame as a landscape of French imperialism. For example, many memes compare the gravity of the loss of Notre-Dame to the loss of the Amazon rainforest, the loss of endangered species or the loss of human life. In this way, these images are saying 'Don't look at this. It isn't important. Instead, look at this. It is". These images, in particular, employ Finnegan's conception of magnitude in that they are using the fire at Notre-Dame compared with other catastrophes as a different kind of "educational document of social fact" to reframe the conversation to a critical activism perspective (Finnegan, 2015: 131). Moreover, they are grounding the visual conversation in the language of shame. They are saying, "You should be ashamed to care more about Notre-Dame than this more pressing issue." These images also implicitly demand policy action around these same issues. Lastly, with $\mathrm{X}$ users, publishing these images on Instagram demands increased visibility for these images. 


\section{Final remarks: Making Images Matter}

The images within the \#NotreDameFire hashtag exist in a particular socio-historical time and place and can only be understood by framing them within this context. In addition to the contextual clues provided in each of the four sections dedicated to an image's capacity to produce presence, communicate character, appropriate popular culture and mobilize magnitude, the fire at the iconic cathedral also was preceded by a series of other calamitous events that likely informed Instagram viewers and content creators' perspectives on the event. In June 2017, a massive fire destroyed Grenfell Tower (a public housing block in London), killing 72 people and decimating both the tower and many surrounding homes. Outside of the United Kingdom, it is a catastrophe most global citizens still know nothing about. In late March and early April before the Notre-Dame fire broke out, three black churches were burned down by a white sheriff's son in Louisiana across a 10-day arson spree. Although coverage was prevalent in the United States for a short period, it quickly waned before being dwarfed by stories about the Notre-Dame fire. On Easter Sunday, just days after the Notre-Dame fire, a series of violent bombings by Muslim extremists devastated churches across Sri Lanka, killing at least 359 people. Despite no one dying in the Notre-Dame fire, it still seemed to receive far more coverage than the other fires (and bombings) across the world. These messages, for many, were loud and clear - the sight of an historic landscape in peril deserves more "air time" than racism, violent extremism or poor people's lives.

When the public recognizes these injustices but has little or no power to address them, where do they turn? In today's modern mediated world, increasingly to social media. Finnegan (2015: 124) argues that "photographs shape citizens' experience of national life and are routinely mobilized by citizens as resources for public argument". If this is the case, and I believe it is, then Instagram as a visual digital archive seems the most likely of the social media platforms for citizens and decolonial scholars to use as a resource in this way. Moreover, in the specific context of social media such as Instagram, it clearly is not only photographs that shape experience and mobilize citizens - art, illustrations, memes, etc. can do the same work when collected via hashtag. They do so through their unique capacities for presence, character, appropriation and magnitude. In this way, a visual digital archive such as Instagram can not only provide a vehicle for sympathetic messages in line with the dominant narrative but also potentially problematize that narrative and organize political resistance to the colonial legacy of symbolic landscapes like Notre-Dame. Whether we like it or not, the political reality in today's context is that traditional ideals of citizenship often stand in stark contrast to reality, and this disproportionately effects young people who are called out for being disengaged (Dahlgren, 2009: 13). Perhaps, as Dahlgren (2009: 14) suggests, part of 
moving beyond the current conundrum in which we find ourselves means "finding new ways to embody and express democratic values and principles, rather than try to reconstruct circumstances that have become historically eclipsed". Perhaps, despite its somewhat ambiguous and contradictory nature, Instagram hashtag activism is one such way.

\section{References}

Benjamin, W. (2010). The work of art in the age of mechanical reproduction (first published 1936). New York, NY: Prism Key Press.

Bonilla, Y. \& Rosa, J. (2015). \#Ferguson: Digital protest, hashtag ethnography, and the racial politics of social media in the United States. American Ethnologist, 42(1), 4-17.

Connors, J.L. (2007). Popular culture in political cartoons: Analyzing cartoonist approaches. PS: Political Science and Politics, April, 261-265.

Finnegan, C.A. (2015). Making photography matter: A viewer's history from the Civil War to the Great Depression. Chicago, IL: University of Illinois Press.

Finnegan, C.A. \& Kang, J. (2004). "Sighting" the public: Iconoclasm and public sphere theory. Quarterly Journal of Speech, 90(4), 377-402.

Hariman, R. \& Lucaites, J.L. (2007). No caption needed: Iconic photographs, public culture, and liberal democracy. Chicago, IL: University of Chicago Press.

Huhtamo, E. (2011). Dismantling the fairy engine. In E. Huhtamo \& J. Parikka (Eds.), Media Archeology: Approaches, Applications, and Implications (27-47). Berkeley: University of California Press.

Jenkins, H., Ito, M. \& boyd, d. (2016). Participatory culture in a networked era. Malden, MA: Polity Press.

Loza, S. (2013). Hashtag feminism, \#SolidaritylsForWhiteWomen, and the other \#FemFuture. A Journal of Gender, New Media, and Technology, 5, n.p.

McIntyre, L. (2018). Post-truth. Cambridge, MA: MIT Press.

Mirzoeff, N. (2016). How to see the world: An introduction to images, from self-portraits to selfies, maps to movies, and more. New York, NY: Basic Books.

Mitchell, W.J.T. (1994/2002). Landscape and power (2nd ed.). Chicago: University of Chicago Press.

Morris, R. (1993). Visual rhetoric in political cartoons: A structuralist approach. Metaphor and Symbolic Activity, 8(3), 195-210.

Mottahedeh, N. (2015). \#iranelection: Hashtag solidarity and the transformation of online life. Stanford, CA: Stanford University Press. 
Panofsky, E. (1955). Meaning in the visual arts: Papers in and on art history. New York, NY: DoubleDay.

Pickard, V. (2016). Media failures in the age of Trump. The Political Economy of Communication, 4(2), 118122.

Stoler, A.L. (2016). Duress: Imperial durabilities in our times. Durham: Duke University Press.

Williams, S. (2015). Digital defense: Black feminists resist violence with hashtag activism. Feminist Media Studies, 15(2), 341-344.

\section{Periodicals and Social Media}

Breeden, A. (2019). Millions in Notre-Dame Donations Pout in as France Focuses on Rebuiling. The New York Times. Retrieved from https://www.nytimes.com/2019/04/17/world/europe/donate-notre-dame-fire.html.

EmmanuelMacron. (2019, April 15). Cette cathédrale Notre-Dame, nous la rebâtirons. Tous ensemble. C'est une part de notre destin français. Je m'y engage: dès demain une souscription nationale sera lancée, et bien au-delà de nos frontières. [Tweet]. Retrieved from https://twitter.com/EmmanuelMacron.

Eustachewich, L. \& Perez, C. (2019). Notre Dame cathedral might never be the same, experts warn. New York Post. https://nypost.com/2019/04/16/notre-dame-cathedralmight-never-be-the-same-experts-warn/.

GoArchitect (2019). The People's Notre-Dame Cathedral Design Competition.

Retrieved from https://www.goarchitect.co/products/the-peoples-notre-dame-cathedraldesign-competition.

Gonzalez, R. \& Horsley, S. (2019). Donation pledges roll in for Notre Dame's reconstruction. NPR. Retrieved from

https://www.npr.org/2019/04/16/714116303/donation-pledges-roll-in-for-notre-damesreconstruction.

Lyons, K. (2019). Notre Dame fire: Macron promises to rebuild cathedral within five years. The

Guardian. Retrieved from https://www.theguardian.com/world/2019/apr/17/notre-damefire-macron-promises-to-make-cathedral-more-beautiful-than-before.

Lough, R. \& Pailliez, C. (2019). France asks - should Notre-Dame's spire by rebuilt as it was? Reuters. Retrieved from https://af.reuters.com/article/worldNews/idAFKCN1RS0B8.

Lough, R. \& Pineau, E. (2019). French President Macron hopes to rebuild Notre-Dame in five years. Reuters. Retrieved from https://www.reuters.com/article/us-francenotredame-probe/french-president-macron-hopes-to-rebuild-notre-dame-in-five-yearsidUSKCN1RSOAV.

Notre-Dame fire: Macron says new cathedral will be 'more beautiful' (2019, April 17), BBC News. Retrieved from https://www.bbc.com/news/world-europe-47957400. 
Prior, R. (2019). The entire wooden interior of Notre Dame Cathedral has been lost. CNN. Retrieved from https://www.cnn.com/style/article/nortre-dame-fire-oak-woodtrnd/index.html.

realDonaldTrump (2019, April 15). So horrible to watch the massive fire at Notre Dame Cathedral in Paris. Perhaps flying water tankers could be used to put it out. Must act quickly! [Tweet]. Retrieved from https://twitter.com/realDonaldTrump.

Meredith L. Pruden is a doctoral student in the Department of Communication at Georgia State University. Her focus lies in cultural studies, with specific attention to feminist media studies, digital culture and visual communication. She has several journal articles under review and presented her research at diverse conferences. She is an inaugural doctoral research assistant on a Facebook grant exploring the internationalization of far-right publics, and serves as an NCA Feminist and Gender Studies Division Graduate Student Representative. With a professional background as a journalist, her goal is to be a public intellectual working at the intersection of academia and the popular press.

凶mpruden1@gsu.edu 